\title{
Preface and Acknowledgments
}

In 1994 I received a Fulbright grant to join a research group at the Centre national de la recherche scientifique (CNRS) in Paris to study French musical life during the Second World War. I arrived in August to a city celebrating the fiftieth anniversary of France's liberation from German occupation. I assumed that, in exploring the wartime activities of French composers, I would be conducting historical research-writing a case study, as it were, of music, politics, and national identity. Yet, at a Fulbright reception before the research group's first meeting, two elderly French music lovers insisted to me that no French music had been performed in wartime France. The only music they had heard in occupied Paris, they informed me, was German music played by German military bands. At the same time, French radio stations were marking the anniversary of the liberation by airing commemorative broadcasts of wartime recordings by French ensembles, interspersed with interviews of aging French musicians about their wartime experiences. This startling juxtaposition of denial and homage was the first of several indications that the highly charged circumstances of the Second World War in France-the swift defeat by the German army and the humiliating armistice with Hitler in June 1940, the ordeal of foreign occupation, the moral complexities of France's wartime Vichy regime, and the unresolved ambiguities of the French Resistance-were still a matter of lively national debate.

This book addresses three misconceptions about music in France during the Second World War. The first, expressed to me by the elderly music lovers at the 1994 Fulbright reception, is that French music and musicians played a negligible role in the cultural life of wartime France. The decadeslong reluctance of the French to acknowledge that their compatriots played key roles in any aspect of life in wartime France inspired the historian 
Henry Rousso in 1987 to devote an entire book to what he memorably called the "Vichy syndrome": the postwar French pattern of alternately repressing and obsessing about the traumas of Vichy and the German occupation. ${ }^{1}$ Although several historians—particularly after Robert O. Paxton's landmark Vichy France: Old Guard and New Order was published in 1972- have written in detail about life in wartime France, French musical life during the war has been slow to receive scholarly treatment. The 2001 publication La vie musicale sous Vichy, a collection of essays summarizing the findings of the CNRS research group I joined in 1994, was the first comprehensive study of the subject to appear. ${ }^{2}$ My current book builds on subsequent publications by members of the CNRS research group, including my 2000 doctoral dissertation, in narrating the cultural and political significance of French music during the war. More specifically, I investigate the ways in which both the Vichy regime and the French Resistance were heavily invested in fostering creative expression through contemporary music in wartime France.

The second misconception that I address in this book is that we can now, nearly seventy years after the liberation, make definitive moral judgments about the activities of composers who lived and worked in wartime France. Part of the ongoing fascination with France during the Second World War is an intense curiosity about whether well-known figures will turn out to have been heroes or villains, résistants or collaborateurs. Yet, whereas writers who published arguments for or against collaboration with Germany are relatively easy to categorize in this way, there are few people in the performing arts who belonged clearly to either camp. To complicate matters further, most of France's non-Jewish musicians, actors, and filmmakersand even a few of the Jewish ones-remained in France throughout the occupation and worked, with German approbation, in institutions that were left intact after the disastrous days of June 1940. The vast majority of French musicians and performers operated in the gray zone that historian Philippe Burrin has described as "accommodation," or acts that occurred "out of necessity, as the least of all evils, and often necessitated compromise, even if it was not always easy to determine when compromises became compromising." 3

After the war a few prominent figures in each industry whose actions went beyond merely continuing their careers were officially sanctioned for collaboration, such as pianist Alfred Cortot, for his concert tours in Germany and for his administrative work with high-ranking Vichy officials; singer-songwriter Charles Trenet, for having sung in Germany, albeit for French prisoners of war and conscripted factory workers; filmmaker 
Henri-Georges Clouzot, for having made films for the German-owned Continental Films; and actress Arletty, for her public affair with a German officer. Yet their sanctions were highly contested and their alleged misdeeds soon forgiven, with nearly everyone involved resuming successful professional careers within a year or two. Resistance, when it happened, occurred largely behind the scenes, by those-such as Édith Piaf and Roger Désormière-whose very willingness to perform in public for audiences of German soldiers mixed with French civilians in occupied Paris was what gave them cover for their activism on behalf of the persecuted and the displaced.

Composers were no different. Like their counterparts in music performance, theater, and film, those who were criticized after the war-most notably, Arthur Honegger - were the ones who had taken the calculated risk of assuming that culture and politics operated in separate spheres. The ones hailed as heroes-led by Francis Poulenc - had been canny enough to foresee that after the war the two spheres would be seen as intricately linked. I discuss what we know about each composer's choices, how those choices were judged in the decades following the war, and whether those postwar judgments were applied fairly to all concerned. But it is not my intention to pass judgment on those choices. I seek instead to explore the ways in which shifting judgments about those choices have affected what their wartime compositions have meant, and continue to mean, to postwar audiences.

Why postwar, and not simply wartime, audiences? Because the third misconception I address in this book is one that I myself held upon my arrival in Paris in August 1994: that the story of French music composed and performed during the Second World War is a story that belongs to the historical past. Composers in wartime France faced difficult, often terrifying choices about how to interact with the Vichy regime as well as with German occupying forces. Postwar ambivalence in France about those choices-and about Vichy in general-has made it difficult, if not impossible, to write objectively about their wartime compositions in the postwar period. By telling both the wartime and postwar histories of these pieces, I show how difficult it is to separate postwar reception from historical narrative about their wartime genesis and, in some cases, first performances. I also show how the postwar repression of the rich musical life of wartime France has impeded our understanding of debates about music and politics in France during the early cold war, for those debates were steeped in subtexts and innuendos about composers' wartime pasts. Lastly, I demonstrate how repression of the wartime histories of music composed during the war has had unintended political consequences in present-day France. 
In September 1994 the effusive celebrations of the fiftieth anniversary of the liberation gave way to renewed recriminations about Vichy and the occupation when the journalist Pierre Péan published a new biography of then president François Mitterrand. ${ }^{4}$ The book caused a stir, for it described not only Mitterrand's youthful involvement with the Vichy regime, but also his postwar support for former Vichy official René Bousquet, accused of crimes against humanity for his role in the persecution of Jews in France. The controversy was such that Mitterrand defended himself on prime-time television in a ninety-minute interview that raised more questions than it answered. ${ }^{5}$ After his death in January 1996, several selections from Maurice Duruflés Requiem were performed at Mitterrand's public funeral mass at the Cathedral of Notre Dame in Paris, which was attended by the entire French government and sixty-one heads of state from around the world. One of my earliest research findings had been an official government form, no longer than half a sheet of paper, filled out and signed by Duruflé on 21 January 1948. ${ }^{6}$ The form indicated that Duruflé's Requiem had fulfilled his 1941 state commission from Vichy's Administration of Fine Arts. Surely the uncanny appropriateness of this music for Mitterrand's funeral mass was entirely unintended and, if known, would have been decidedly unwelcome. When the CNRS research group published its findings in 2001, I contributed an article on the Vichy commissions in which I discussed the origins of Duruflés Requiem in the government's wartime program. ${ }^{7}$ The fact that this article met with an angry denial from Frédéric Blanc, the president of the Association Maurice et Marie-Madeleine Duruflé, confirmed for me what the unwitting use of Duruflés Requiem at Mitterrand's funeral mass already suggested: that there was a powerful story to be told not just in the wartime genesis of pieces such as the Requiem, but also in the political and musical implications of that genesis for their performance today.

Rousso followed his original study of the Vichy syndrome with three sequels. The Mitterrand controversy in September 1994, the landmark apology in July 1995 by Mitterrand's successor, Jacques Chirac, for France's "collective responsibility" for Vichy's role in the Holocaust, and the conviction of former Vichy official Maurice Papon in 1998 for crimes against humanity provided Rousso and his coauthor, journalist Éric Conan, with many media debates to discuss. ${ }^{8}$ My work shares with Rousso and Conan's the desire to explore the complexities of France's past and the manifestations of that past in the global present. The political and legal events they discuss have bearings, both direct (such as the use of Duruflés Requiem for Mitterrand's funeral mass) and indirect (such as the stigma of the label 
"Vichy commission" for that same Requiem) on the postwar reception of music composed in wartime France.

But the study of the presence of France's wartime musical compositions in postwar culture necessarily differs from that of politics, literature, and film, for music must be re-created every time it is performed. Musicians often seek to learn about the history of the music they are to perform or record, and music, as an art whose meanings are not always expressed clearly in words or visible symbols, often comes with verbal explanations: preconcert talks, program notes, liner notes, performance reviews. Whether the war experience is highlighted, downplayed, simplified, suppressed, or explored in depth is at stake every time the music is played.

What is more, several of the wartime compositions I discuss are audience favorites around the world on a scale vastly exceeding that of French novels or films from or about the war. The most famous of the wartime piecesOlivier Messiaen's Quartet for the End of Time, Honegger's Symphonie pour cordes, and Poulenc's Figure humaine-are celebrated in recent recordings for their value as wartime testimonies. One can also currently find commercially available CDs of the wartime works of Georges Auric, Elsa Barraine, Henri Dutilleux, and André Jolivet. ${ }^{9}$ What sustains interest in these works appears to be not (or not only) the aesthetic appeal of their sounds, however appealing some of them may be, but rather the emotional intensity of their wartime stories. Their stories-of music's ability to distract, console, resist, incite outrage, and help endure captivity-are universalized for a global audience.

In The Musical Legacy of Wartime France, I expand upon my earlier historical research by addressing two questions: what stories do we tell each other about the music of wartime France, and why should any of these stories, including my own, matter to today's performers and audiences? For the first question I use reception history, finding the stories in postwar secondary sources and tracing them back to their original tellings, which were often published or recorded as interviews in the decade following the liberation of France. For the second, I propose close readings of musical scores to demonstrate how the historical circumstances of wartime France affected the music that was composed in that time and place. Composers' responses to their surroundings are bound to be varied, for composers, perhaps more than their counterparts in literature and film, can select the degree to which their music represents particular events in sound. Music can bear witness to harrowing events, but, since music — particularly instrumental music without a written text or program-need not portray specific situations, it can also provide a creative means of escape from one's surroundings. 
In January 1997, the front page of Le Monde featured a bleakly funny political cartoon that combined French anxieties about the trials of prominent former Vichy officials for wartime crimes with the discovery that artwork stolen from Jewish owners remained in the collections of France's national museums. In the cartoon, a massive statue of Marshal Pétain draping his arm around a grinning Hitler sits in a dark warehouse, covered with cobwebs. A museum guard at the door comments, "It's very interesting, this work of art, yet no one is reclaiming it!" (fig. I). This cartoon encapsulates the ways in which I made some of my most surprising research discoveries. For instance, in March 1995, when I asked to see a score by the little-known composer André Gailhard at the music library of Radio France, an overworked librarian brought me a pile of papers from the library's closed stacks. She had brought me everything she saw under Gailhard's name, she told me, to save herself a trip. The score I had requested was now irrelevant, for the librarian had unwittingly unearthed the orchestral score and parts to Gailhard's Ode à la France blessée (Ode to a wounded France), a 1941 state commission narrating the French war experience in words and music from the official perspective of Vichy's National Revolution. Gailhard's Ode had been preserved on the shelves, but it had been omitted from the library's catalog. More recently, in June 2009, I asked Patrick Le Boeuf, a librarian in the theater arts department of the Bibliothèque nationale, to check screenwriter Bernard Zimmer's papers for any drafts of the text Zimmer had provided to Honegger for his long-lost secret Resistance song, Chant de Libération. I was stunned when Le Boeuf notified me one week later that Zimmer's papers contained a score of the piece, missing since its October 1944 premiere amid French recriminations about Honegger's wartime interactions with German occupying forces. These scores were hidden, as it were, in plain sight-as if, although no one had destroyed them, someone had hoped they would go unnoticed.

In their 1994 study Vichy: An Ever-Present Past, Conan and Rousso described the recent obsession with the Vichy regime in France as having distorted France's postwar exploration of its wartime past by focusing too narrowly on Vichy's anti-Semitism. This focus, they argued, is not only anachronistic, for most Vichy officials did not see anti-Semitism as central to their own projects, but it also risked marginalizing other forces at play in wartime France, such as the German occupying forces with which the Vichy regime collaborated and the diverse movements of resistance that rose up at different times and with differing motivations. ${ }^{10}$ In music, heightened awareness of the Holocaust has notably skewed the postwar reception of Messiaen's Quartet. Although it was composed and premiered in 1941 in a 


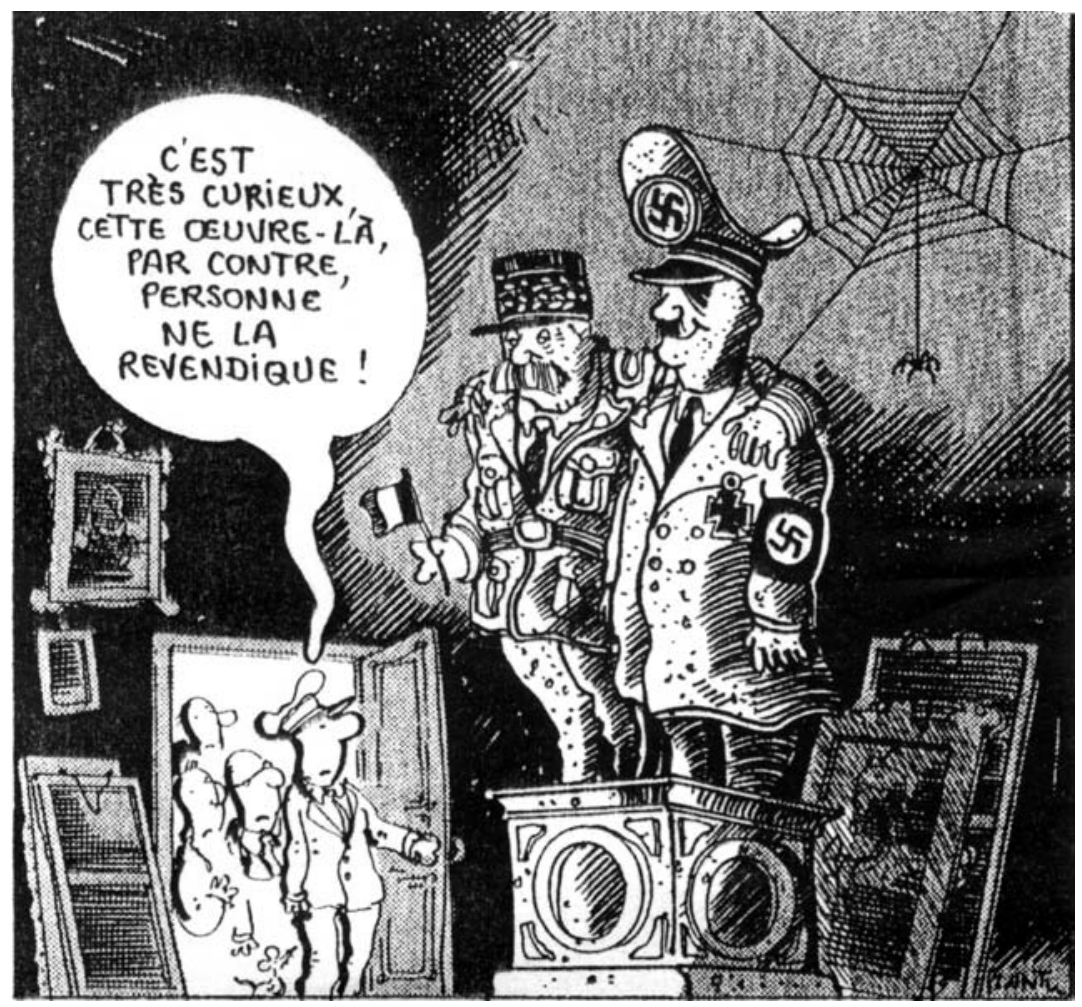

FIGURE 1. Political cartoon, Le Monde, 28 January 1997, by Plantu. The caption reads: "It's very interesting, this work of art, yet no one is reclaiming it!"

German prisoner of war camp, recent recordings and radio broadcasts, in their haste to group Messiaen's music with that of concentration camp victims and survivors, have passed over crucial differences between Messiaen's experiences in a prison camp like Stalag VIIIA in Silesia and Viktor Ullmann's in Theresienstadt. ${ }^{11}$ It is more common, however, that postwar stories about wartime compositions have focused not on Vichy and its crimes but on the issue of collaboration or resistance. How should we judge, for example, musicians' decisions to remain public figures when those decisions entailed interactions with German authorities? How do we square that with the postwar celebration of those same public figures as having resisted the Germans? As a result of these preoccupations, the stories of musicians actually marginalized by French anti-Semitic legislation, such as Manuel Rosenthal and Marcel Mihalovici, have themselves been marginalized in postwar accounts. The music world is just beginning to call attention 
to the impact of Vichy's anti-Semitic legislation and persecution on the musicians and composers working in wartime France.

The chapters of The Musical Legacy of Wartime France are organized chronologically and thematically. Of all the stories I tell, the story of Poulenc's music is the most confined to the actual war years. Because his wartime compositions generated interest among all three of the competing political and administrative forces in France-the German occupiers, the Vichy regime, and the Resistance-I use his story in chapter 1 to provide an overview of these forces that serves as background to all five chapters in the book. The stories in chapters 2, 3, and 4 move back and forth between the wartime histories of the works I discuss and their postwar reception. Along with chapter 1 , they present parallel explorations of two central issues faced by composers in wartime France: whether to continue one's career in the face of dramatic political changes; and, if so, then how to negotiate those changes.

Chapters $I$ and 2, on the music of Poulenc and Honegger, respectively, compare the wartime choices and postwar fates of two of France's bestknown composers. Both of them made a conscious decision to continue pursuing their careers in occupied Paris, where they enjoyed significant professional success despite the altered political landscape: their major wartime premieres include Poulenc's ballet Les Animaux modèles at the Opéra and Honegger's Symphonie pour cordes, performed by Charles Münch and the Société des Concerts du Conservatoire. Poulenc emerged from the war years with his reputation intact, finding eager and receptive postwar audiences for Figure humaine, his a cappella choral setting of the Resistance poetry of Paul Éluard, composed in secret in 1943. Honegger's more controversial wartime choices preceded his composition in early 1944 of Chant de Libération, a song for baritone solo, unison chorus, and orchestra that received one performance in liberated Paris before French musicians imposed a six-month ban on the composer's music in retaliation for what they regarded as acts of collaboration. I juxtapose Chant de Libération with Chant de la Délivrance (Honegger's postwar pastiche of a Resistance song) in order to explore the role of Honegger's music in his postwar rehabilitation. The swiftness of his rehabilitation, moreover, calls into question the seriousness of his wartime offenses.

Chapters 3 and 4 take a close look at contrasting postwar narratives about the wartime compositions of two of France's most devout Catholic composers, Messiaen and Duruflé. If Duruflé's Requiem is notable for the long postwar denial of its historical connections to wartime France, Messiaen's Quartet for the End of Time has become emblematic of the 
French wartime experience for today's listeners-one of whom was even inspired to write a two-hundred-page novel based on the work's genesis and first performance in captivity. ${ }^{12}$ In these two chapters I seek to reverse the terms of the postwar debate. In chapter 3 I contrast Messiaen's Quartet with Jolivet's musical and verbal documentary Trois Complaintes $d u$ soldat to discuss the ways in which the Quartet demonstrates Messiaen's remarkable ability to write ethereal music that transcends his physical ordeals more than it engages with them. Duruflé, who originally envisioned his Requiem as an organ suite, was commissioned in 1941 specifically to write a symphonic poem, destined for performance by one of occupied Paris's symphony orchestras, which were receiving state subsidies to promote new French music. In chapter 4 I argue that Duruflé set aside the unfinished organ suite as well as a hypothetical a cappella choral setting in order to fulfill the terms of the commission. The Requiem is unique among his compositions in the symphonically conceived orchestral accompaniment he provided to choral parts that are based only intermittently on plainchant. Thus the work we indelibly associate with the war-Messiaen's Quartet-is arguably less permeated by the circumstances of its composition than the one-Duruflés Requiem-whose connections to its wartime past have long been overlooked or repressed by critics concerned with its "timelessness." My goal for these chapters is to place each composer's expressions of religious faith in a dialectical relationship with the impact of his surroundings.

Chapter 5, though a postwar story, is one that is nevertheless haunted by France's wartime past. Paris may have been liberated in August 1944, but the war in France was far from over, both literally-enemy troops were not completely defeated in France until the unconditional surrender of German forces in Europe in May 1945-and figuratively. Although initially the student protests that met the Paris premieres of Stravinsky's latest works in early 1945 concerned aesthetics-the rejection of Stravinsky's continued embrace of prewar neoclassicism in his wartime works-rather than politics, the fact that the students chose to heckle works by one of the most prominent composers in prewar France touched a raw nerve among older French composers. In this chapter several of the composers from chapters 1 through 4 make a final appearance: Auric, Poulenc, and Jolivet as music critics, and Messiaen as an influential teacher to the protesters. Stravinsky's defenders-in particular Auric and Poulenc, both associated with the Resistance during the war-made ominous references to the questionable wartime choices of not only Jolivet, who supported the protesters in print, but also Émile Vuillermoz, who merely showed up at the concerts. At the 
same time, in protesting such vigorous defense of Stravinsky's neoclassicism, Serge Nigg and his classmates were rejecting the very idea of a national musical tradition in France, an idea that the discredited Vichy regime had worked hard to promote. Soon, however, Nigg's membership in the French Communist Party meant that he would face pressure from the Soviet Union, applied to communist composers worldwide in 1948, to replace "falsely cosmopolitan tendencies" with references to his national heritage. Thus I argue that we risk misconstruing the choices made by French musicians during the cold war if we fail to acknowledge the lingering impact of the occupation on the cultural landscape of early postwar France.

The stories each of us tells are shaped, of course, not only by the information available to us, but also by our predilections. In 2009 the historian Timothy Snyder argued that we have overlooked the reasons why Auschwitz-erroneously, in his opinion-is at the center of our Holocaust narratives, as embodied in the now-famous novels of Tadeusz Borowski, Primo Levi, and Elie Wiesel. Snyder reminds his readers that since Auschwitz, unlike the death camps of Treblinka, Bełżec, and Sobibor and the mass open-air massacres in eastern Europe, functioned as both labor and death camp, its inmates had a higher rate of survival. In addition, unlike eastern European survivors living behind the iron curtain, western Europeans who survived Auschwitz were "free to write and publish as they liked" after the war. As for the riveting photographs and films taken at the liberation of Auschwitz, according to Snyder, "they are not the whole story" of German and Soviet mass murder; "sadly, they are not even an introduction." ${ }^{13}$ They are, however, the stories we have preferred. It is time to ask why.

Musicians, audience members, and scholars are understandably attached to the stories they already know about the music of wartime France. In these pages I offer updated versions in which the detailed information now available is far richer, but at times far darker, than the familiar myths. Recently the art curator Maya Benton, who discovered that the photographer Roman Vishniac presented a misleading portrait of prewar European Jewish life by selecting for postwar publication only stereotypical images of shtetl life, expressed her hope that a forthcoming exhibit of Vishniac's unpublished work would present a more vivid panorama of a vanished world. "Why are people so attached to the other story?" she remarked to a reporter for the New York Times. "The real story is so much better."14 Once, after I presented my research on Messiaen's Quartet to a group of conservatory faculty and students, a professor asked me if I even liked Messiaen's 
music. In fact, I became enthralled with pieces such as Duruflé's Requiem, Honegger's Symphonie pour cordes, Messiaen's Quartet, and Poulenc's Figure humaine as a musician long before I reexamined them as a scholar. It is my fascination with them as music that has compelled me to look into the complexities often masked by stereotyped narratives of redemption through art. My research has changed not only the way I think about these pieces, but the way I hear them as well. It has also changed my assumptions about the study of music and politics. I hope to show that, in addition to the ways in which political circumstances shape music composition and music in turn shapes politics, politics can continue to influence our perception of musical favorites, and vice versa, long after the sounds of their initial performances have faded.

Several people were instrumental in the research, writing, and publication that led to this book. Myriam Chimènes, who in 1994 extended the invitation to me to join the CNRS research group La vie musicale en France pendant la Second Guerre mondiale, has generously provided advice, feedback, and crucial contacts among French musicians and researchers ever since. She also invited me to present my research in Paris numerous times at the CNRS and at a study session at the 1997 Congress of the International Musicological Society in London. Members of the research group gave me invaluable tips along the way. My thanks go to Agnès Callu for advice about the purification files at the Archives nationales; Hélène Eck and Karine Le Bail for sharing their knowledge of sources on France's wartime radio stations; Guy Krivopissko and Daniel Virieux for meeting with me at the Musée de la Résistance nationale in Champigny-sur-Marne; and Manuela Schwartz for providing me with relevant information on wartime France from German archives. The staff at the music and theater arts divisions of the Bibliothèque nationale de France were patient with my requests for documents and information. I thank Patrick Le Boeuf in particular for his help with the Fonds Bernard Zimmer. I also received welcome help from the staff of the Archives des affaires étrangères at the Ministère des Affaires étrangères et européennes, the Archives nationales, the Bibliothèque de documentation internationale contemporaine, the Bibliothèque Jean Maitron at the Centre d'histoire sociale du XXe siècle, the Centre de documentation musicale at Radio France, the Institut d'histoire du temps présent, the Institut national de l'audiovisuel, and the Médiathèque Musicale Mahler. Michèle Noirjean-Linder and Robert Piencikowski were very accommodating during my brief visit to the Paul Sacher Foundation in 
Basel. Unless otherwise indicated, all translations from French or German are my own.

In the United States, Richard Taruskin provided steady support and insightful feedback when I was ready to follow my dissertation with this, its sequel. Thanks to Richard, to Mary Francis and her colleagues at the University of California Press, and to the anonymous peer reviewers for crucial help in revising and publishing the manuscript. Any remaining errors or omissions are, of course, entirely my own. Musicology colleagues Danielle Fosler-Lussier, Peter Schmelz, Joy Calico, Eric Drott, Barbara Milewski, Robert Fallon, Sally Bick, and Chris Murray provided sympathetic and astute feedback on chapter drafts and conference papers. At Drew University I have received valuable support from faculty members Anne Yardley, Norman Lowrey, Trevor Weston, Wendy Kolmar, and Kimberly Rhodes. Special thanks for research assistance go to Kathleen Juliano and her staff in the Interlibrary Loan office at Drew University, and to Ruthann McTyre, head of the Rita Benton Music Library of the University of Iowa, as well as to the students and faculty who participated in the colloquia I gave at those two institutions. My original dissertation research was supported by a Fulbright grant to France; an Alvin H. Johnson AMS 50 Dissertation Fellowship from the American Musicological Society; and the Doreen B. Townsend Center for the Humanities, the Department of Music, and the Chancellor's Dissertation Fellowship at the University of California, Berkeley. Later stages of research received welcome financial support from an Old Gold Summer Fellowship for Non-Tenured Faculty at the University of Iowa, from the Office of the CLA Dean at Drew University, and a Wallerstein Partnership grant from the Center on Religion, Culture, and Conflict at Drew University.

It was enormously helpful to share my work with panel members and audiences at the American Musicological Society's annual meetings in Columbus, Ohio, in 2002 and Indianapolis in 2010, at sessions chaired, respectively, by Pamela Potter and Laura Silverberg; the Lyrica Society for Word-Music Relations panel "Old Texts/Modern Music" at the annual convention of the Modern Language Association in Philadelphia in 2009, chaired by Jeff Dailey; and the Conference on Music and Politics at the University of Bristol in 2010, organized by Pauline Fairclough. I am especially grateful to Peter Schmelz for having invited me to participate in the panel "Music and Politics in the Early Cold War: Recent Approaches, Future Directions," sponsored by the AMS Cold War and Music Study Group at the American Musicological Society's national meeting in Quebec City in 2007. The lively discussion that evening of the panelists (Phil Ford, Danielle 
Fosler-Lussier, Tamara Levitz, Peter Schmelz, and Laura Silverberg) and the audience members elucidated my thinking on Boulez, Nigg, Stravinsky, and the cold war in France.

Before I researched the music of wartime France, I played it. As my ideas on twentieth-century French music have evolved, I have often been inspired by the conversations and instruction I received from my piano teachers. Elaine Greenfield introduced me to Debussy's piano music and, through an unforgettable live performance at the Adamant Music School, Messiaen's Quartet. Charles Abromavic guided me through learning selections from Messiaen's Vingt regards sur l'Enfant-Jésus, with which I unwittingly surprised Pierre Petit, then director of the École normale de musique in Paris, when I proposed to play them as my audition for the school in 1988 (at his request I played Schumann instead). Through my teacher there, Françoise Parrot-Hanlet, I met Jean Françaix and pianist Vlado Perlemuter, who held a master class on the music of his teacher, Ravel. Among the memorable performances I attended that year was the November 1988 concert celebrating Messiaen's eightieth birthday, performed by Pierre Boulez, Yvonne Loriod, and the Ensemble Intercontemporain. These early exposures to major figures of twentieth-century French musical life inspired me to select a research topic for my dissertation that would enable me to return to France to study it more closely. Once in the libraries and archives of Paris, I took notes when I came across intriguing information on familiar pieces, such as Messiaen's Quartet and Honegger's Symphonie pour cordes, that were nevertheless outside the scope of my dissertation research. Those notes were the first steps in writing this book.

Last but not least, I owe a great deal to my daughters, Audrey and Lena, for their patience with my more distracted moments over the years of research and writing. I thank them, too, for their tolerance of my research trips to Paris, especially in spring 2010, when my return was delayed by an erupting Icelandic volcano. Those trips were greatly enlivened by the friendship and hospitality of Édith Grua-Étienbled, Hollis Krym, and Nicolas Choussat. 
